Reprod. Nutr. Develop., 1988, 28 (3 B), 817-818

\title{
Glucose utilization by fetal muscles during maternal fasting
}

\author{
S. HAUGUEL, A. LETURQUE, M. GILBERT (*), J. KANDÉ, J. GIRARD
}

Centre de Recherches sur la Nutrition, C.N.R.S.,

9, rue Jules Hetzel, 92190 Meudon, France.

(*) Collège de France, Physiologie du Développement

11. place Marcelin Berthelot, 75005 Paris, France.

Summary. In utero, glucose utilization by fetal muscles (heart and hindlimb) displays important interspecies differences. In the fed state, it is 5 -fold higher in rat than in rabbit fetal muscles. Maternal fasting induces a decrease in glucose utilization in fetal muscles of the rat but not of the rabbit.

During pregnancy, fasting induces important endocrine and metabolic adaptations in the mother [review in (6) and (4) ]. These changes are associated to a sparing of glucose by maternal tissues (particularly in muscles) in order to insure adequate availability of fuels and metabolites to the fetus (6). Since skeletal muscle is the largest fetal tissue (3) the present work was initiated to answer the following question: is glucose utilization by fetal muscle modified during maternal fasting?

Material and methods. - Rats of the Wistar strain and rabbits of the "Fauve de Bourgogne " strain were used. The animals had free access to water and commercial food (65\% carbohydrate, $24 \%$ protein, $11 \%$ fat for the rat, $68 \%$ carbohydrate, $22 \%$ protein, $10 \%$ fat for the rabbit). Rat fetuses were delivered by cesarean section on day 19 of gestation and rabbit fetuses on day 29 of gestation after $0 \mathrm{~h}, 48 \mathrm{~h}$ and $96 \mathrm{~h}$ of maternal fasting. Fetal blood substrate (glucose and ketone bodies) and plasma insulin concentrations were determined. Glucose utilization indexes in fetal tissues were measured by a tracer technique using the glucose analog 2-deoxy- $\left[1-{ }^{3} \mathrm{H}\right]$ glucose (1) adapted to the rat fetus (5). Results were expressed as glucose utilization indexes (i.e. ng of 2-deoxyglucose-6phosphate accumulated per minute per $\mathrm{mg}$ of tissue wet weight) rather than absolute rates of glucose utilization since the discrimination factor for 2deoxyglucose against glucose transport and phosphorylation was not determined.

Results. - In the rat, fetal glycemia was decreased after $48 \mathrm{~h}(0.23 \pm 0.04 \mathrm{vs}$ $0.52 \pm 0.05 \mathrm{~g} / 1$ and $96 \mathrm{~h}(0.22 \pm 0.03 \mathrm{vs} 0.52 \pm 0.05 \mathrm{~g} / \mathrm{l})$ of maternal fasting without modifications of fetal insulin level. In the rabbit, fetal glycemia remained constant after a $96 \mathrm{~h}$ maternal fast, but plasma insulin concentration was decreased from $115 \pm 2$ to $21 \pm 4 \mu \mathrm{U} / \mathrm{ml}$. As a matter of fact, the glycemia of 
96-h fasted mothers was decreased by $30 \%$ in the rat but remained unchanged in the rabbit (data not shown). The effects of maternal fasting on blood glucose concentration in fetal rat and rabbit are readily explained by the fact that fetal glycemia is directly correlated to maternal glucose concentrations [review in (2)]. Fetal ketone body concentrations were elevated by ten-fold after $96 \mathrm{~h}$ of maternal fasting in the rat $(3.2 \pm 0.6 v s 0.43 \pm 0.08 \mathrm{mmol} / \mathrm{l})$ and remained constant in the rabbit $(0.4-0.5 \mathrm{mmol} / \mathrm{l})$ despite a ten-fold increase in maternal concentrations. Thus, ketone bodies are not readily transferred across the rabbit placenta, contrarily to the rat. Glucose utilization indexes of the heart and hindlimb muscle were measured in fetuses from fed and fasted mothers. In the fed state, glucose utilization by fetal muscles was higher in the rat than in the rabbit (fig. 1 and 2), indicating important interspecies differences. In the rat, glucose utilization index was decreased by $30 \%$ in the fetal heart after $48 \mathrm{~h}$ and $96 \mathrm{~h}$ of maternal fasting and by $50 \%$ in fetal hindlimb muscles after $96 \mathrm{~h}$ of maternal fasting. By contrast, $96 \mathrm{~h}$ of maternal fasting in the rabbit did not modify the already low glucose utilization index of fetal heart or hindlimb muscles. These results indicate that in the rabbit the rate of glucose utilization by fetal muscle was not affected by hypoinsulinemia when blood glucose concentration remained constant.

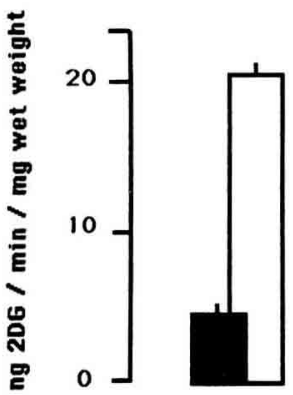

on

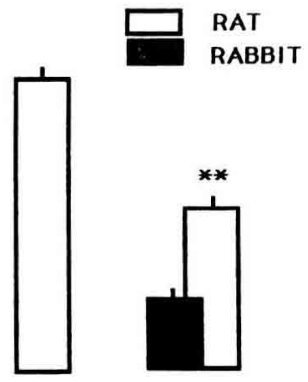

96h

$48 \mathrm{~h}$

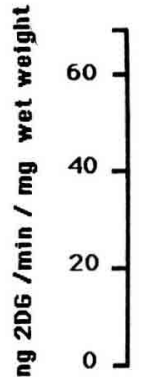

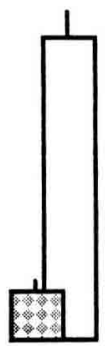

oh

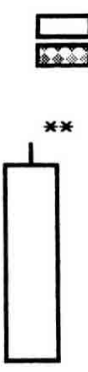

$48 \mathrm{~h}$
RAT RABBIT

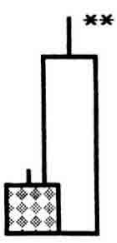

$96 \mathrm{~h}$

FIG. 1. - Glucose utilization index in hindlimb muscles of fetuses from fed (0 h) and fasted mothers $(48 \mathrm{~h}, 96 \mathrm{~h})$. Results are mean \pm SEM of 14 fetuses from fed mothers and 10 fetuses from fasted mothers. ${ }^{*}$ Difference statistically significant for $\mathrm{p}<0.01$ between fed and fasted animals.

FIG. 2. - Glucose utilization index in the heart of fetuses from fed ( $0 \mathrm{~h})$ and fasted mothers ( $48 \mathrm{~h}$, $96 \mathrm{~h}$ ). Results are mean \pm SEM of 14 fetuses from fed mothers and 10 fetuses from fasted mothers. ** Difference statistically significant for $p<0.01$ between fed and fasted animals.

In conclusion, these studies demonstrate important interspecies differences in glucose utilization indexes by fetal muscles in both fed and fasted states. During maternal fasting, the decreased rate of glucose utilization by fetal muscles seems to be related to the changes of fetal glycemia rather than to those of fetal insulinemia.

(1) Ferré P., Leturque A., Burnol A. F., Pénicaud L., Girard J., 1985. Biochem. J., 228, 103-110.

(2) Girard J., Pintado E., Ferré P., 1979. Ann. Biol. anim. Bioch. Biophys., 19, 181-197.

(3) Jones C. J., Ralph P. H., 1985. Physiol. Rev., 65, 357-430.

(4) Leturque A., Hauguel S., Ferré P., Girard J., 1987a. Biol. Neonate, 51, 64-69.

(5) Leturque A., Revelli J. P., Hauguel S., Kandé J., Girard J., 1987b. Am. J. Physiol., 253, E616-E620.

(6) Metzger B. E., Vileisis R. A., Ravnikar V., Freinkel N., 1982. Lancet, 1, 588-592. 